\title{
Chapter 8 \\ The Changing Landscape \\ of Sustainability Standards in Indonesia: \\ Potentials and Pitfalls of Making Global \\ Value Chains More Sustainable
}

\author{
Clara Brandi
}

\section{Introduction}

Development pathways have to be altered to make them both more environmentally sustainable and socially inclusive. ${ }^{1}$ To be environmentally sustainable, development must be reconciled with planetary boundaries. To reduce poverty, development must be inclusive, such that it benefits all members of society. These two approaches can entail both synergies and conflicts. For instance, solar panels can give poor people access to low-carbon energy. Meanwhile, ecologically sustainable energy or food production may increase costs and consumer prices, or production of biofuels may crowd out food production, thereby compromising food security. Synergies have been investigated in focusing on concepts such as the "Green Economy" (UNEP, 2011), "Green Growth" (OECD, 2011) and "Inclusive Green Growth" (World Bank, 2012). UNEP's Green Economy Initiative sets the stage for the transition to a green economy that is low carbon, resource efficient and socially inclusive. OECD's Towards Green Growth Initiative provides a framework for achieving economic growth and development while preventing environmental degradation. World Bank's Inclusive Green Growth sets out a pathway to sustainable development. These concepts explicitly focus on the positive and reinforcing interlinkages between environmental sustainability and development. The related trade-offs, however, have not been in the limelight yet (Brandi, 2016). Against this background, this chapter assesses the potential trade-offs between socio-economic and green dimensions of development in the

\footnotetext{
${ }^{1}$ Substantial parts of this chapter have previously been published in Brandi (2016), "Sustainability Standards and Sustainable Development: Synergies and Trade-offs of Transnational Business Governance", Sustainable Development, 25(1), 25-34.

C. Brandi $(\bowtie)$

German Development Institute/Deutsches Institut Für Entwicklungspolitik (DIE), Bonn, Germany e-mail: clara.brandi@die-gdi.de
} 
context of sustainability standards for palm oil and proposes practical ways to address these trade-offs.

Palm oil gives rise to both substantial positive socio-economic as well as negative environmental and social impacts, generating important questions at the nexus of environmental sustainability and socio-economic development issues (Brandi, 2015). On the one hand, the palm oil sector poses a lucrative source of income by offering a high return on land and labour and can function as an important engine for rural socio-economic development. At the same time, the palm oil sector has serious negative impacts regarding environmental sustainability, including reduced biodiversity and massive greenhouse gas emissions when forest and peatland are replaced (Danielsen et al., 2009; Sheil et al., 2009). Hosting tropical forests and peatlands that count among the world's largest, Indonesia serves as a good example to illustrate the increasing relevance of sustainability standards in the sector.

Over the last years, rising sustainability concerns regarding palm oil have triggered various standard-setting and certification initiatives. The most important initiative is the Roundtable on Sustainable Palm Oil (RSPO), a private-driven multi-stakeholder standard and certification scheme that entails third-party verification that the product under consideration is in compliance with the given principles and criteria of the RSPO standard. In recent years, there has been a significant increase in regulatory initiatives to develop private voluntary sustainability standards. The literature refers to this boom as the rise of "civil regulation" (Vogel, 2008) or the "certification revolution" (Conroy, 2007).

At the same time, lately, the landscape has started to change. For example, in Indonesia, the government recently introduced the "Indonesian Sustainable Palm Oil" (ISPO) initiative, a mandatory government-led certification scheme. The rise of ISPO illustrates the recent trend in terms of public actors reclaiming certification authority through state-led, mandatory schemes, undermining the private transnational certification institutions in support of government-driven certification regimes (Hospes, 2014; Giessen et al., 2016; Wijaya \& Glasbergen, 2016). The interaction between private and public authorities in the governance of environmental and social challenges is still an understudied field of global governance. This paper will shed light on it with a particular emphasis on the effects for smallholders and potential trade-offs between socio-economic and green dimensions of sustainable development.

It is essential to include smallholders into certification schemes-both from an environmental sustainability and from a socio-economic development perspective. Any sustainability standard is more effective from an economic, environmental and social perspective if it includes this important group. At the same time, certification of smallholders is challenging, as it demands a set of financial, managerial and agronomic capacities that smallholders in most cases lack. While smallholder certification can be a promising instrument in order to contribute to inclusive green growth, there are important potential trade-offs between environmental sustainability and inclusive development: First, there is a worry that the diffusion of private standards that aim at enhancing environmental sustainability may undermine the socio-economic situation of smallholders-in so far as standards generate market exclusion. Second, 
while smallholder certification can generate socio-economic benefits for farmers who are a part of certification schemes, these benefits may have perverse implications for environmental sustainability-in so far as they increase incentives to expand palm oil plantations, including into forested areas. This chapter analyses these trade-offs and discusses practical implications with a view to fostering the synergies between economic and environmental sustainability in the context of sustainability standards and smallholder certification. The chapter focuses on the private-driven RSPO but also discusses the public-driven ISPO and examines what their interaction might imply for the above-mentioned trade-offs.

The findings in this chapter are based on secondary sources as well as primary data collected through a smallholder survey as well as interviews with various stakeholders. To collect the data, field research was conducted within the context of four RSPO smallholder certification projects in four different provinces in Sumatra, comprising both independent and scheme smallholders. The survey was conducted with 196 independent smallholders. In addition, 71 semi-structured interviews with smallholders, heads of small smallholder groups, mill and plantation company staff, and experts were conducted.

The remainder of the chapter is structured as follows. Section 2 underlines the importance of smallholder certification and Sect. 3 outlines the benefits of RSPO certification for smallholders and assesses trade-offs between socio-economic and green dimensions of development in the context of private-driven sustainability standards for palm oil. Section 4 discusses the implications of the interaction between private- and public-driven certification schemes for the trade-offs under consideration. Section 5 offers concluding comments, focusing on how trade-offs in the context of smallholder certification can be managed and what lessons may emerge for other sectors as well as for other countries.

\section{The Importance of Smallholder Certification}

Rising concerns about the negative effects of palm oil production have led to the emergence of sustainability standards and certification schemes. For palm oil, RSPO is the most prominent private-driven standard-setting body so far (Brandi, 2016, p. 26). RSPO, a multi-stakeholder voluntary initiative founded in 2004, brings together major actors from the palm oil supply chain with NGOs in order to promote the growth and use of sustainable palm oil through credible global standards. Through multi-stakeholder consultations, the Roundtable has developed a set of principles and criteria (P\&C) for sustainable palm oil production and has been implementing independent certification of growers according to these P\&C since 2008. RSPO standards cover a broad range of sustainability aspects with regard to the environmental and social effects of palm oil production. The relevant certification criteria require the following aspects: compliance with laws and regulations; transparency; economic long-term planning; good agricultural practices; social responsibility for employees and the rights of communities; environmental responsibility; and the protection of 
high conservation value areas (RSPO, 2007). For each of the criteria, indicators exist that are verified on the ground by auditors during the certification process.

Including smallholders into certification schemes is essential-in the palm oil sectors and beyond it (Brandi, 2016, p. 26). Overall, smallholders account for around $85 \%$ of the 525 million farmers worldwide (Nagayets, 2005, p. 2; FAO, 2012, p. 56). These smallholders and their livelihoods are important both from a development as well as from an environment perspective. They can be both a hurdle for the "mainstreaming" of certification (Steering Committee of the State-of-Knowledge Assessment of Standards and Certification, 2012) or play the beneficial role of "managed ecosystems" (Swinton, 2008). In Indonesia, more than one million smallholders are an essential element of the palm oil sector. They account for $38 \%$ of cultivation area and 35\% of production output (Indonesian Palm Oil Commission, 2012) and are of central relevance for processes of sector change. A social and sustainabilityoriented transformation of the palm oil sector can only be realized on the basis of their cooperation and inclusion in sustainability standards and certification schemes.

Certification schemes have to include the important group of smallholders for two main reasons: for environmental reasons and in order to help smallholders to improve yields and quality of their production and to avoid potential exclusion from standard-sensitive markets. ${ }^{2}$

Environmental Reasons for Smallholder Inclusion The large-scale environmental impacts from oil palm cultivation stated above-greenhouse gas emissions through land-use conversion, loss of biodiversity and deforestation-occur through the expansion of large plantations and through smallholder palm oil expansion and production alike. Smallholder certification can be regarded as a potentially promising complementary instrument to the enforcement of environmental laws and regulations in establishing more sustainable oil palm cultivation (Brandi, 2016, pp. 29-30).

Certification causes smallholders to improve their often poor agronomic practices, thereby reducing small-scale negative environmental impacts. Smallholders often use poor agronomic practices when they lack the relevant knowledge relating to integrated pest management, correct application of agrochemicals, soil management via intercropping, modalities of land conversion (use of fire to clear forest) and the illegality of hunting protected animal species, of which there have been increasing reports over the past several years. Knowledge and capacity-building as well as rising environmental awareness in the process of preparing for the certification of sustainability standards can generate spill-over effects and help in other fields of environmental action in rural regions. Smallholders using better agronomic practices offer the potential to realise yield increases on already existing cultivation areas. In this way, overall palm oil production can potentially be increased in a sustainable way without converting primary forests.

RSPO aims at reducing negative environmental impacts, including large-scale concerns such as deforestation and associated negative effects on ecosystems. On the ground, as the empirical findings of this study suggest, a private standard like RSPO

\footnotetext{
${ }^{2}$ The remainder of this section is based on Brandi (2016), pp. 29-31.
} 
struggles to effectively combat large-scale problems within the existing institutional framework. At the same time, voluntary standards can contribute towards reducing negative environmental impacts on a small scale. Potential small-scale environmental benefits include reduced chemical usage via the application of an integrated pest management system, soil quality improvements (e.g. higher soil fertility), erosion control, improved waste management and buffer zones near rivers.

Economic Reasons for Smallholder Inclusion Smallholder certification can generate a number of important economic benefits for smallholders, including increases in yields and better quality of fruit and price premiums (Brandi, 2016, p. 29). The improvement of capacities in the process of gaining certification leads to spill-over effects on other activities. The training smallholders receive for better agronomic management, and organisational and economic planning is expected to strongly improve the efficiency of their agricultural and economic activities. Moreover, the potential premium for certified sustainable palm oil paid in international markets or the direct sale of certificates like Green Palm can potentially generate additional income for smallholders and contribute to improving their livelihoods. The certification of smallholders thus offers economic development opportunities, especially for rural regions. Smallholder development and its social multiplier effects are the main drivers for rural development, thus making it essential that smallholders realise the above-stated market access and benefit via certification. Additionally, the certification process can incorporate stronger supply chain cooperation, thus lowering production costs, raising productivity to a better quality level and stabilizing supply through risk diversification.

There are two types of smallholders in Indonesia. While scheme smallholders are tied to a formal partnership, Nucleus Estate Smallholder (NES) scheme, with a palm oil company and are receiving important technical assistance, knowledge and inputs, independent smallholders, on the other hand, operate independently through all phases of production. This chapter puts the spotlight on the latter since information on the certification of independent smallholders is particularly scarce. There have been few smallholder certifications so far, especially independent ones. In 2010, the first Indonesian scheme smallholders were certified under RSPO. In 2012, the first independent smallholders were certified in Thailand. In Indonesia, the first independent smallholders, a smallholder association in Riau, received certification from the RSPO in 2013, constituting the second such certification of independent smallholders in the world. Subsequently, the association of independent smallholders Tajung Sehati in Jambi was also certified under RSPO.

\section{Economic and Environmental Sustainability: The Risk of Trade-Offs}

To what extent are there trade-offs between socio-economic and environmental sustainability in the context of private-driven oil palm smallholder certification? This 
section begins by discussing whether the socio-economic dimension of sustainability is coming under pressure in the context of smallholder certification being used as a tool to foster environmental sustainability before it turns to a discussion on whether environmental sustainability is at risk in the context of supporting smallholders to become certified and comply with sustainability standards in the palm oil sector. ${ }^{3}$

Smallholder Exclusion First, there is a worry that the diffusion of standards that aim at enhancing environmental sustainability may undermine the socio-economic situation of smallholders. Current certification schemes might exclude smallholders because they are dominantly designed for large-scale agro-industry requiring costs and capacities that are often out of reach for most smallholders. The concern is that smallholders may be excluded from international markets that demand certified palm oil.

There is no consensus in the literature regarding the question whether and under which conditions standards cause market exclusion for smallholders. While some studies disagree, the literature frequently suggests that, while their impact is contextspecific, private standards may indeed undermine smallholder market participation and that the threat of exclusion in case of non-compliance with certification standards can be significant for smallholders (e.g. Herzfeld et al., 2011; Elbehri et al., 2013; Schuster \& Maertens, 2013; Loconto \& Dankers, 2014). The underlying fear is that smallholders who are not certified cannot gain access to markets that require compliance with sustainability standards and that non-certified smallholders are excluded from these markets. Moreover, most authors argue that stringent standards imperil smallholder participation in global value chains because sourcing from numerous smallholders is more costly for companies, for example, due to higher transaction costs for monitoring conformity and the need for more intensive farm extension (Reardon et al., 1999; Swinnen, 2007). In other words, certification systems could lead to the exclusion of smallholders from international trade. This is a substantive fear among policy makers and development practitioners.

However, the research conducted on smallholder certification in Indonesia has shown that independent smallholders have so far not been confronted with exclusion from markets in general. Only very few independent smallholders mentioned explicitly that they saw a benefit in being able to contribute to satisfy international demand for sustainable palm oil with their production. For instance, China and India, as well as the domestic Indonesian market, are still largely sourcing non-certified palm oil. Since the demand is strong enough to absorb non-certified palm oil, independent smallholders are still able to sell their production output to non-certified mills. Thus, as long as international demand for non-certified palm oil remains unchanged, or rises, and markets requiring compliance with sustainability standards remain small, non-certified smallholders are not confronted with complete market exclusion.

Perverse Incentives Second, while smallholder certification can generate socioeconomic benefits for farmers who are a part of certification schemes, above all by

\footnotetext{
${ }^{3}$ This section is based on Brandi (2016), pp. 30-31.
} 
increasing yields, socio-economic benefits of certification may have perverse implications for environmental sustainability. This in turn can lead to increased economic attractiveness of oil palm cultivation and increased financial capacity of the smallholder to buy land for expanding palm oil plantation areas. If expansion takes place in forested areas, it constitutes a contradiction to a key aim of sustainability standards for palm oil. The survey conducted with palm oil smallholders in Indonesia included a question regarding the expansion of their palm oil plots into forested areas. Almost $40 \%$ of smallholders who answered the question stated that they would expand into an area that is covered by forest.

Thus, RSPO certification might lead to a perverse incentive scheme concerning expansion into forest areas. Nevertheless, the decision of the smallholder to expand depends on a variety of factors, such as personal motivation, world market prices of palm oil and other financial needs. Nevertheless, this problem of a possible perverse incentive scheme for independent smallholders has to be taken into account in the context of RSPO certification processes.

\section{The Changing Standards Landscape and Its Implications}

Recently, with the rise of public-driven standards and certification schemes, the landscape of sustainability standards has begun to change. In 2010, ISPO was established, a mandatory government-led certification scheme. The launch of ISPO is largely driven by a struggle between the national level, especially the government and domestic producer companies, and the international level, above all international NGOs and their influence in the RSPO. For instance, the chair of the Indonesian Palm Oil Committee (IPOC) explicitly characterized the challenge of sustainable palm oil as an Indonesian problem that has to be solved at the national level rather than one that concerns the international community. A second important driver for the launch of ISPO was competition for market shares. For instance, the chair of IPOC made it clear that the aim of ISPO is to enhance the competitiveness of Indonesian palm oil in global markets (Suharto, 2010).

What does the interaction between the private-driven and the public-driven certification schemes imply for the trade-offs mentioned above? Overall, ISPO is (even) less demanding than RSPO. First of all, ISPO imposes less stringent requirements for many environmental issues. ISPO lacks $11 \%$ of the indicators found in the RSPO, including an indicator on high conservation value (HCV) (Salim, 2014). Moreover, in the context of ISPO, many key social issues are missing or vaguely worded (Paoli, 2013). For instance, ISPO does not contain the concept of "free, prior, informed consent" (FPIC), wherein consent for plantation development or local community land-use change is to be obtained in a "free, prior and informed" way from affected individuals and communities.

What does the launch of ISPO imply for smallholders? On the one hand, the interplay of public and private standards can give rise to inefficiencies and put a burden 
on producers, especially small ones, if they have to become certified under different standards. On the other hand, public-driven schemes may take better account of small producers or smallholders than private-driven ones in so far as states "claim back their regulatory power, playing back their role in granting and enforcing citizens' rights" (Bartley, 2014). While the potentially dysfunctional interaction of public and private standards can burden producers, especially small ones, the case at hand suggests that the public-driven scheme may actually take better account of small producers or smallholders than private-driven ones. The high financial and administrative costs make certification almost impossible for small producers and smallholders without additional support, potentially leading to their exclusion from the international market. With state-driven schemes like ISPO, states seem to re-claim their role in taking care of their citizens. Indeed, ISPO has put a spotlight on certifying smallholders, arguably a stronger one than the private-driven RSPO, despite efforts to include smallholder interests in that context as well. It is sometimes even argued that ISPO was introduced to eventually develop a standard that is better applicable to smallholders. In 2015, the Indonesian Ministry of Agriculture and UNDP began the process of pilot testing the guidelines for ISPO smallholder certification (UNDP, 2015), addressing the need to focus on smallholders (Salim, 2014). At the same time, smallholders would still be likely to face severe challenges when adopting ISPO (Jong, 2018). Moreover, since there is no comprehensive roadmap for integrating smallholders, the implementation of ISPO in that context might end up being ineffective (Yuliawati, 2016).

Overall, the above-mentioned trend towards more public-driven initiatives might affect potential trade-offs between social and environmental dimensions of sustainability. The case of palm oil suggests that while the public-driven scheme may take better account of small producers or smallholders than the private-driven one, ISPO is less demanding than RSPO in terms of a number of relevant environmental challenges.

\section{Conclusion}

While sustainability standards and smallholder certification have the potential to create substantial socio-economic benefits for smallholders, large-scale environmental benefits focussing on deforestation and greenhouse gas emissions are found to be difficult to achieve. ${ }^{4}$ Only small-scale environmental benefits such as reduced usage of agrochemicals seem realistic. One major reason for limited effectiveness in environmental terms is that sustainability standards like RSPO are not without loopholes and face implementation and control challenges. Overall, private sustainability standards alone can hardly solve all relevant environmental problems of palm oil production, for example, indirect land-use change. In order to be effective, standards

\footnotetext{
${ }^{4}$ See also Brandi (2016), pp. 31-32.
} 
need a favourable economic and institutional environment. The formulation of a standard's P\&C implies difficult trade-offs thus private sustainability standards cannot provide all-encompassing solutions for all problems. As discussed above, sustainability standards are meant to contribute to solving dilemmas such as that between a lucrative sector of the economy producing income and jobs, on the one hand, and its negative environmental impacts, on the other hand. Yet, the development and implementation of such standards creates new dilemmas.

This chapter has shown that aiming for "sustainable development" or "inclusive green growth" on the basis of smallholder certification is challenging and can entail major trade-offs. First, there is a worry that the diffusion of standards that aim at enhancing environmental sustainability may undermine the socio-economic situation of smallholders. Since smallholders can access certified markets only through group certification, they need to organize cooperatives or other types of smallholder groups. Even more importantly, smallholder certification usually requires external support as it demands capacities that smallholders often lack. The concern is that, without external support, smallholders may, in the future, be excluded from international markets that demand certified palm oil.

Second, while smallholder certification can generate socio-economic benefits for farmers who are a part of certification schemes, these benefits may have perverse implications for environmental sustainability. Training associated with certification can increase the smallholders' productivity and thus their income from palm oil. This in turn can lead to increased economic attractiveness of oil palm cultivation and increased financial capacity of the smallholder to buy land for expanding palm oil plantation areas. If expansion takes place in forested areas, it constitutes a contradiction to a key aim of sustainability standards for palm oil. The current specification of the RSPO P\&C thus entails a potential contradiction between RSPO goals to foster socio-economic and environmental sustainability at the same time. Productivity gains related to RSPO certification can potentially lead to increased expansion into forest or protected areas. This perverse incentive scheme might contradict the aim of RSPO to combat deforestation. In order to avoid such contradictory outcomes, control and safeguard mechanisms should be implemented-especially in smallholder certification projects.

More recently, the landscape of sustainability standards has begun to change. In the light of the rise of private-driven certification initiatives, there is a need for more research on the interaction between private- and public- driven certification schemes and its implications for smallholders and for the trade-offs examined in this chapter. In the shorter run, the introduction of state-driven schemes like the one assessed in this chapter arguably creates more fragmentation by being added to the existing ones-especially since they seem to be triggering the introduction of even more national standards in other sectors and in other countries that are following the example set by ISPO. For example, the Indonesian Ministry of Forestry created a mandatory certification system for the forest sector (Giessen et al., 2016) and after the establishment of ISPO, the Ministry of Agriculture initiated a similar approach for the rubber sector asking a third party for the creation of a draft for a national rubber certification scheme. Moreover, the launch of ISPO has triggered the introduction 
of additional, potentially competing and national standards for palm oil. In 2015, the Government of Malaysia, ranked second in terms of volume after Indonesia, introduced the MSPO standard, explicitly "following in the footsteps of Indonesia" (Adnan, 2013). Moreover, Brazil has also introduced national schemes for palm oil and soy (Hospes, 2014).

More research is also needed on how the shift towards national public-driven certification schemes and their interaction with private-driven governance initiatives affects the environmental, social and economic sustainability of the sectors under consideration in the longer run. In the shorter run, the introduction of national publicdriven schemes, at least in the case at hand, seems to be beneficial for smallholders but appears to lead to the introduction of a lower standard, especially from the point of view of environmental sustainability.

How can the trade-offs between economic and environmental sustainability in the context of smallholder certification be managed? One possible approach could be that when joining a smallholder group, smallholders should sign a contract forbidding the establishment of new plots in forested areas-be it nearby or in other provinces. The breach of such a contract should attract the withdrawal of the certificate of the whole group or exclude the particular member of the group in order to generate social pressure. In addition, special training should be provided that focuses on the benefits of environmentally sustainable production for the smallholders. Overall, the environmental aims of smallholder certification should be given the same attention, from the beginning, as the socio-economic aims. Possible contradictions between these two sets of goals should be managed, or at least be made transparent-both in the Indonesian palm oil sector but also in other sectors and in other countries as well.

\section{References}

Adnan, H. (2013). National palm oil standard soon. The Star. 21 March. Available at URL: http://www.thestar.com.my/Business/Business-News/2013/03/21/National-palm-oil-sta ndard-soon.aspx.

Bartley, T. (2014). Transnational governance and the re-centered state: Sustainability or legality? Regulation \& Governance, 8, 93-109.

Brandi, C. (2015). Sustainability standards for palm oil-Challenges for smallholder certification under the RSPO. The Journal of Environment \& Development, 24(3), 1-23.

Brandi, C. (2016). Sustainability standards and sustainable development: Synergies and trade-offs of transnational governance. Sustainable Development, 25(1), 25-34.

Conroy, M. E. (2007). Branded! how the certification revolution is transforming global corporations. Minneapolis: Consortium Book.

Danielsen, F., et al. (2009). Biofuel plantations on forested lands: Double Jeopardy for biodiversity and climate. Conservation Biology, 23, 348-358.

Elbehri, A., Segerstedt, A., \& Liu, P. (2013). Biofuels and the sustainability challenge: A global assessment of sustainability issues, trends and policies for biofuels and related feedstocks. Rome: FAO.

FAO (Food and Agriculture Organization of the United Nations) (2012). The state of food and agriculture. Rome: Author. Retrieved from http://www.fao.org/docrep/017/i3028e/i3028e.pdf. 
Giessen, L., Burns, S., Sahide, A., \& Wibowo, A. (2016). Governance to government: The strengthened role of state bureaucracies in forest and agricultural certification. Policy and Society, 35(1), $71-89$.

Herzfeld, T., Drescher, L., \& Grebitus, C. (2011). Cross-national adoption of private food quality standards. Food Policy, 36, 401-411.

Hospes, O. (2014). Marking the success or end of global multi-stakeholder governance? The rise of national sustainability standards in Indonesia and Brazil for palm oil and soy. Agriculture and Human Values, 31(3), 425-437.

Indonesian Palm Oil Commission. (2012). Indonesian palm oil statistics 2010. Jakarta: IPOC.

Jong, H. N. (2018). Are small farmers ready as Indonesia looks to impose its palm oil sustainability standard on all? Available at URL: https://www.eco-business.com/news/are-small-farmers-readyas-indonesia-looks-to-impose-its-palm-oil-sustainability-standard-on-all/.

Loconto, A., \& Dankers, C. (2014). Impact of international voluntary standards on smallholder market participation in developing countries - A review of the literature. Rome: FAO.

Nagayets, O. (2005). Small farms: Current status and key trends. Information brief prepared for The Future of Small Farms Research Workshop at Wye College, UK. Retrieved from http://cit eseerx.ist.psu.edu/viewdoc/download?doi=10.1.1.146.4632\&rep=rep1\&type=pdf.

Organization for Economic Co-operation and Development (OECD). (2011). Towards green growth. Paris: Author.

Paoli, G. D., \& Yaap, B. (2013). A comparison of leading palm oil certification standards applied in Indonesia: Towards defining emerging norms of good practices. Bogor: Daemeter.

Reardon, T., Codron, J. M., Busch, L., Bingen, J., \& Harris, C. (1999). Global change in agrifood grades and standards: Agribusiness strategic responses in developing countries. International Food and Agribusiness Management Review, 2(3), 421-435.

RSPO. (2007). RSPO principles \& criteria for sustainable palm oil production. Kuala Lumpur: Roundtable on Sustainable Palm Oil.

Salim, T. (2014). Palm oil certification gets int'l support. The Jakarta Post. 4 October. Available at URL: http://www.thejakartapost.com/news/2014/10/04/palm-oil-certification-gets-int-1-support. html.

Schuster, M., \& Maertens, M. (2013). Do private standards create exclusive supply chains? New evidence from the Peruvian Asparagus export sector. Food Policy, 43, 291-305.

Sheil, D., et al. (2009). The impacts and opportunities of oil palm in Southeast Asia. In Occasional Paper, Centre for International Forestry Research (ed.). Bogor: Centre for International Forestry Research.

SCSKASC (Steering Committee of the State-of-Knowledge Assessment of Standards and Certification). (2012). Toward sustainability: The roles and limitations of certification. Washington, DC: RESOLVE Inc.

Suharto, R. (2010). Why Indonesia needs ISPO. The Jakarta Post. December 2. Available at URL: http://www.thejakartapost.com/news/2010/12/02/why-indonesia-needs-ispo.html.

Swinnen, J. F. M. (2007). Global supply chains, standards and the poor. Oxon: CAB International.

Swinton, S. M. (2008). Reimagining Farms as Managed Ecosystems. Choices, 23(2), 28-31.

UNDP (United Nations Development Programme) (2015). Indonesia palm oil platform (InPOP). Newsletter, 15(1). Jakarta: Author. Available at URL: http://www.undp.org/content/dam/undp/ library/Environment\%20and\%20Energy/Green\%20Commodities\%20Programme/UNDP\%20N ewsLetter\%20Final\%20Final.pdf.

UNEP (United Nations Environment Programme). (2011). Towards a green economy: Pathways to sustainable development and poverty eradication. Nairobi: Author.

Vogel, D. (2008). Private global business regulation. Annual Review of Political Science, 11, 261282.

Wijaya, A., \& Glasbergen, P. (2016). Toward a new scenario in agricultural sustainability certification? The response of the Indonesian national government to private certification. The Journal of Environment and Development, 25(2), 219-246. 
World Bank. (2012). Inclusive green growth: The pathway to sustainable development. Washington, D.C.: World Bank.

Yuliawati, Devi. (2016). Power dynamic in smallholders' participation in sustainable certification: A case study of Indonesian sustainable palm oil certification. Department of Human Geography: University of Lund.

Open Access This chapter is licensed under the terms of the Creative Commons Attribution 4.0 International License (http://creativecommons.org/licenses/by/4.0/), which permits use, sharing, adaptation, distribution and reproduction in any medium or format, as long as you give appropriate credit to the original author(s) and the source, provide a link to the Creative Commons license and indicate if changes were made.

The images or other third party material in this chapter are included in the chapter's Creative Commons license, unless indicated otherwise in a credit line to the material. If material is not included in the chapter's Creative Commons license and your intended use is not permitted by statutory regulation or exceeds the permitted use, you will need to obtain permission directly from the copyright holder.

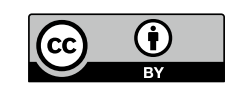

